\title{
Are we wired for spirituality? An investigation into the claims of neurotheology
}

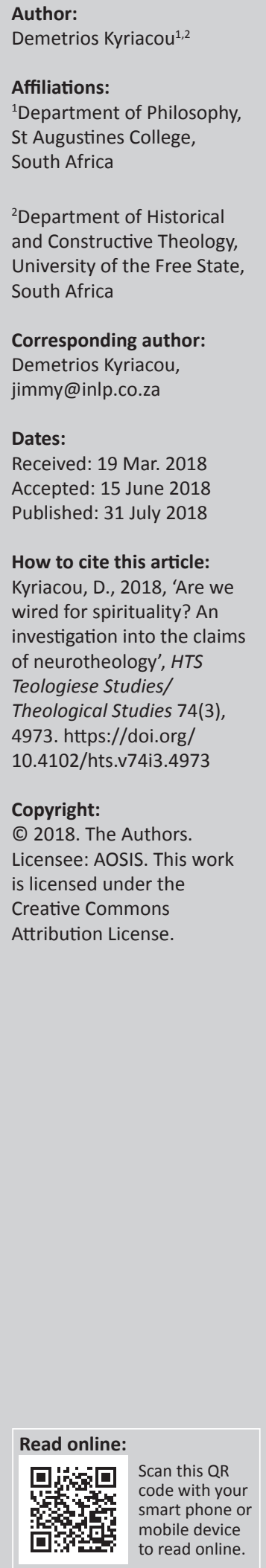

This article is an investigation into the field of neurotheology, a controversial field which has attracted criticism from both the scientific and religious community and which is often quite divided among its own practitioners. Regretfully, but not too unexpectedly, science has gotten entangled with ideology, as we shall see, with proponents on all sides of the spectrum using findings from the laboratory in support of their own philosophical positions. We will begin by exploring some definitions of the field and then move on to examine the claims made by the different scientists working in this area, before examining what conclusions we can draw for spirituality.

\section{Introduction}

'That's a question for a neuro-theologian.' 'Meaning what?', He asked. 'Somebody who thinks about people in terms, simultaneously, of the Clear light of the Void and the vegetative nervous system ...' (Huxley 1962:112).

This article is an investigation into the field of neurotheology, a controversial field which has attracted criticism from both the scientific and religious community and which is often quite divided among its own practitioners. Regretfully, but not too unexpectedly, science has become entangled with ideology, as we shall see, with proponents on all sides of the spectrum using findings from the laboratory in support of their own philosophical positions. We will begin by exploring some definitions of the field and then move on to examine the claims made by the different scientists working in this area, before examining what conclusions we can draw for spirituality. I will conclude by suggesting that Neurotheology as a field has largely been superseded and has been replaced by a more spiritually sensitive approach known as Contemplative Neuroscience.

There is a broader question in the title which sets the frame and provides the context for the investigation into neurotheology and that is the question whether, and to what extent, we are 'wired for spirituality'. In other words, are we, in any sense, somehow predisposed towards the spiritual?

\section{What is neurotheology?}

Neurotheology, also known as spiritual neuroscience, is the study of correlations of neural phenomena with subjective experiences of spirituality and hypotheses to explain these phenomena. Proponents of neurotheology claim that there is a neurological and evolutionary basis for subjective experiences traditionally categorised as spiritual or religious ('Neurotheology', Wikipedia: The Free Encyclopaedia).

Anumber of distinctions are worth highlighting in this definition: Firstly, the term 'neurotheology' is often used interchangeably with the term 'spiritual neuroscience'. Secondly, neurotheology studies correlations between neural phenomena, that is, brain processes, with subjective experiences of spirituality. Thirdly, we have the claim that there is a neurological and evolutionary basis for these experiences. It is in this third area that most of the controversy arises. While the correlations are a matter of factual evidence, the claims for what the correlations imply are subject to debate. We also note that the term 'spiritual experience' remains somewhat unspecified at this point.

Not everybody is open to the correlational study in the first place. Some scientists have called it 'quasi-scientific' and question the validity of the endeavour (Feit 2003:1). Similarly, while some religious believers have expressed suspicion at any attempts to probe the neurobiology of belief, 
thinking that it was somehow irreverent, others have appealed to it in support of claims for the existence of the soul (Beauregard \& O'Leary 2008). In addition, the Media, to a large extent, have 'had a field day' in publicising the various findings and claims in an often sensationalist manner. There is a great deal of potential for a balanced and sober approach to the field which tries to steer an authentic middle ground, allowing the facts to speak for themselves.

\section{The claims of neurotheology}

According to a recent article in the Newsweek magazine:

Neurotheology is stalking bigger game than simply affirming that spiritual feelings leave neural footprints, too. By pinpointing the brain areas involved in spiritual experiences and tracing how such experiences arise, the scientists hope to learn whether anyone can have such experiences, and why spiritual experiences have the qualities they do. (Begley 2001:3)

These are noble and worthwhile questions; if we can understand how spiritual experiences take place, then our spiritual lives would be enhanced and our practices of spiritual formation vastly enriched. Few, surely, could argue with such a treasure. The issue, however, is not so simple. In his review of the book, The Spiritual Brain, by Mario Beauregard and Denyse O'Leary, Bryan Appleyard (2007) has stated:

Neuroscience is a combat zone. It is here, in the human brain, that the final conflict between materialism and, to invent a word, soulism is being fought. For materialists, the outcome is not in doubt. Our minds, ourselves, our awareness, are merely the outcome of the electrical activity of the few pounds of hyperconnected matter between our ears. All claims to the contrary are wishful thinking or superstitious remnants. (p. 1)

Thus, we come to the crux of the controversy surrounding neurotheology: writers committed to a materialist ontology and a reductive approach to the mind are arguing not only for neural correlates to spiritual experience but are wanting to eliminate spirituality entirely by arguing that these experiences are caused by the brain in some manner. Candidates for this causal mechanism vary from evolutionary adaptations to genetic mechanisms, brain modules or circuits of various descriptions, temporal lobe discharges related to temporal lobe epilepsy (TLE), etc. It will be argued in this article that these writers have made an unjustified leap from correlation to causation.

Some religious believers have made the opposite mistake; pointing out that none of these arguments is sufficient to explain spirituality, they want to argue that the only sufficient explanation, therefore, is that these neural phenomena must be pointing to an authentic source of the experiences, namely God and/or the soul.

The challenge for both extremes is pointed out by science writer George Johnson (2007):

In the neurological search for the spiritual, there is no shortage of data. But pile it as high as you like, and you're left staring across the same divide. Depending on your predisposition, you can interpret all these experiments in two different ways. The believers take them as scientific evidence for the reality of their visions, while the atheists claim more proof that God is all in your head. (p. 1)

In the pages ahead, we will examine some of the leading theories and different perspectives in spiritual neuroscience in order to see what we can justifiably infer on the broader question, 'are we wired for spirituality'?

\section{Explaining (Away) religion?}

In The Mystical Mind (Fortress Press, Minneapolis, 1999, p. 4), Newberg and D'Aquili credited the scholar James Ashbrook with introducing the term neurotheology in 1984. In fact, Aldous Huxley used it more than 20 years earlier in his utopian novel, Island (Harper \& Row, New York, 1962, p. 144). (Horgan 2003:74)

While the origins of the term 'neurotheology' go back to 1962, it only came into its contemporary usage in the last two decades, with the development of sophisticated brainscanning technologies such as functional magnetic resonance imaging (fMRI) and computer-assisted tomography scans, which allowed fairly accurate observations of the brain in action without the need for invasive and potentially dangerous surgical procedures. It was only a question of time before researchers began to wonder what might be going on in the brain during spiritual experiences such as prayer or meditation.

According to Beauregard and his colleagues:

[e]volutionary psychology is the theoretical background of neurotheology, which 'analyses the biological basis of spirituality' and 'deals with the evolutionary basis for subjective experiences traditionally categorised as spiritual.' (Beauregard \& O'Leary 2008:208)

Thus, early researchers such as Pascal Boyer started off with rather modest claims about what evolutionary science could say about religion. In his way of thinking, we acquire religious concepts in the same way that we acquire a disposition for the cold or for music appreciation, namely as a result of prior evolutionary developments which had other functions. Boyer (2001) says:

Our minds are prepared because natural selection gave us a very special kind of mind, with particular dispositions. Does this mean that religion is 'innate' and 'in the genes'? I and most people interested in the evolution of the human mind - think that the question is in fact meaningless and that it is important to understand why .... Having a normal human brain does not imply that you have religion. All it implies is that you can acquire it, which is very different. (pp. 4-5)

Nevertheless, around the same time, other thinkers were already laying the foundation for the more specific and daring claims which were to follow. 
Vilayanur Ramachandran, director of the Centre for Brain and Cognition at the University of California at San Diego, raised the stakes by suggesting that his 1997 study had discovered a 'God spot (or module)' in the brain that could underpin an evolutionary instinct to believe in religion. Popular media, the scientific community and the academy have been attracted to this idea that religious belief was somehow 'hardwired' into the human brain in such a module (Beauregard \& O'Leary 2008:35).

While on the one hand Ramachandran has conceded that some of his proposals constitute 'skating on thin ice', he has nevertheless gone on to argue, in his BBC Reith Lectures, for a quite reductionistic approach:

Even though it is common knowledge these days, it never ceases to amaze me that all the richness of our mental life - our religious sentiments and even what each of us regards as his own intimate private self - is simply the activity of specks of jelly in your head, in your brain. There is nothing else. (Beauregard \& O'Leary 2008:58)

However, despite Ramachandran's assurances of 'common knowledge', even if a so-called 'God spot' were to be found, reduction of the 'richness of mental life' merely to 'specks of jelly' would still be entirely unwarranted. We will consider the various claims for this 'God spot (or module)' (Beauregard \& O'Leary 2008:35) in a later section. Also, around the same time 'the New Atheism', as it has been dubbed, represented by thinkers such as Richard Dawkins and Daniel Dennett, was coming to the fore. Thus, in The Selfish Gene, relying on another somewhat controversial idea, that of memes (supposedly the cultural equivalent of genes), Dawkins (1989) asserted:

The survival value of the god meme in the meme pool results from its great psychological appeal. It provides a superficially plausible answer to deep and troubling questions about existence. It suggests that injustices in the world may be rectified in the next. The 'everlasting arms' hold out a cushion against our own inadequacies which, like a doctor's placebo, is none the less effective for being imaginary. (p. 193)

\section{The 'God' part of the brain}

Fellow outspoken atheist Matthew Alper, picking up on both Ramachandran and Dawkins, is more explicit than either of his predecessors and in his book The 'God' Part of the Brain argues that religion is a genetically acquired trait. As he puts it:

Wouldn't the fact that all human cultures, no matter how isolated, have believed in the existence of a spiritual realm suggest that such a perception must constitute an inherent characteristic of our species, that is, a genetically inherited trait? (Alper 2001:67)

It is important to stress that at this stage Alper is providing a philosophical argument. He asks a question, pointing to the widespread pervasiveness over time of religious beliefs and implies that it is 'suggestive'. He draws on Ramachandran and Dawkins and looks forward to a future bio-theology or geno-theology which will confirm his argument. Unfortunately for Alper, however, there are many other explanations for why people believe what they do. We have seen that Boyer provides one example. Another more obvious one may be that the object of belief has some actual basis in reality. It is at least as plausible to argue that it does as to say that it is 'simply' a genetically inherited trait. But what if such a genetic basis could be found? This brings us to the work of Dean Hamer and the story of The God Gene.

\section{The God gene}

Hamer starts from a simple premise: 'Spirituality comes from within. The kernel must be there from the start. It must be part of their genes' (Hamer 2004:49). Hamer (2004) then also places his philosophical cards on the table:

By a scientific explanation, I mean one that can be expressed in terms of the basic principles of chemistry and physics. Proponents of this view often are called 'materialists' because they believe that all mental processes can ultimately be accounted for by a few basic physical laws. Most scientists, including myself, are materialists. (p. 94)

What Hamer does not point out however is that not all scientific explanations are necessarily limited to physics and chemistry. There are biological explanations, for example, and new sciences such as complexity theory and emergence which challenge simple-minded reductive approaches. The reduction of all of the sciences to physics and of all phenomena to matter is far from settled even among rigorous scientists. Furthermore, there are levels of explanation beyond the scientific, such as social, cultural and religious, which may need to be considered. Be that as it may, what evidence has Hamer actually uncovered?

The basic idea behind Hamer's work is that self-transcendence is an adaptive trait (a trait that promotes survival and the ability to produce fertile offspring). As such, he sought it in a gene that we inherit because it is useful. He studied nine genes that promote the production of brain chemicals called monoamines - including serotonin, norepinephrine and dopamine. These chemicals regulate mood as well as motivation. Monoamines are the chemicals that antidepressants attempt to control. He argues that a variation in a gene known as VMAT2 (vesicular monoamine transporter) is the 'God gene' responsible for coding this adaptive trait. (Beauregard \& O’Leary 2008:50)

While Hamer's book was warmly reviewed by the media, fellow scientists have been rather critical.

At one end of the spectrum, physicist and science writer Chet Raymo, who makes it clear that he would like to believe Hamer's thesis, pronounces it 'frail' and hopes others will defend it better. Science writer Carl Zimmer suggests that VMAT2 is best titled. A Gene That Accounts for Less than One Percent of the Variance Found in Scores on Psychological Questionnaires Designed to Measure a Factor Called SelfTranscendence, Which Can Signify Everything From Belonging to the Green Party to Believing in ESP, According to One Unpublished, Unreplicated Study. 
At the far end of the negative spectrum, science writer John Horgan bluntly asks, 'Given the track record of behavioural geneticists in general, and Dean Hamer in particular, why does anyone still take their claims seriously?' (Beauregard \& O'Leary 2008:52).

Coming from the complete opposite side of the spectrum, Beauregard and his colleagues argue for a 'non-materialist' theory of the mind. While we are still to consider their critiques of Ramachandran, Alper, Hamer and others, regretfully their argument also fails on a number of significant grounds. They begin by making a very important, and quite correct, disclaimer:

The external reality of God cannot be directly proven or disproven by studying what happens to people's brains when they have mystical experiences. Demonstrating that specific brain states are associated with spiritual or mystical experiences, neither shows that such experiences are 'nothing but' brain states nor proves that God exists. It shows only that it is reasonable to believe that mystics do contact a power outside themselves. (Beauregard \& O'Leary 2008:38)

While the premises are quite correct, we have to take issue with their conclusion. The correlation of brain states with spiritual experience does not show that they are 'nothing but' brain states, but neither does it show that the mystics' belief in a power outside themselves, while not unreasonable, is entirely reasonable either. It merely suggests that such an outside power may be possible; we shall have to look elsewhere, such as faith or personal experience, for additional grounds of belief. Beauregard and his colleagues have succumbed to the unfortunate tendency of Intellectual Design theorists to go from the failure of scientific explanations to prove something, for example, consciousness, to arguing that this shows that the soul must exist (i.e. it must have been designed).

This is the 'God of the Gaps' fallacy that materialists have been so quick to point out. Furthermore, in not specifying what they mean by 'the soul' or what specifically they mean by a non-materialist theory of the mind (other than that it is not material), an otherwise very useful argument ends up severely compromised. Be that as it may, we shall later examine their research on the neuroscience of spirituality.

\section{Phantoms in the temporal lobe?}

We turn now to two researchers who, like Ramachandran, believe that spiritual experiences are linked to the temporal lobe and that TLE may be a key trigger of the mystical:

In an influential 1997 paper, University of California neurologists Jeffrey Saver and John Rabin claimed that the limbic system of the brain - a system that lies within reach of the temporal lobes and functions as a medium for emotions - plays a pivotal role in RSMEs [religious, spiritual and mystical experiences] ... In their journal article, Saver and Rabin also discuss a distinctive type of religion-prone personality, called a 'temporal-lobe personality', that they associate with temporal-lobe epilepsy. This form of epilepsy can affect the limbic system. Saver and Rabin propose that many great religious figures of the past may have displayed symptoms of TLE. (Beauregard \& O'Leary 2008:60-61)

In Ramachandran's earlier research, he had argued that some $25 \%$ of his research subjects reported a spiritual experience associated with the onset of an epileptic seizure. Saver and Rabin extend the argument to the functions of the nearby limbic system. They argue that the disruption of the normal function of the limbic system in TLE of tasks such as maintaining one's sense-of-self and gauging the significance of one's ordinary surroundings are factors contributing to RSMEs.

Let us, for the sake of argument, accept Ramachandran's percentage. There are still many reasons why a person in the midst of an epileptic seizure might find their thoughts turning to spiritual themes, as they do in many other situations of extreme stress or danger. For the conclusions to have any validity, Ramachandran and his colleagues would have to explain why only $25 \%$ of the subjects have a spiritual experience and not all of them. Furthermore, and more importantly, what is the evidence, from neuroscience, that all of the many other people who have a spiritual experience, however defined, have anything remotely resembling temporal lobe disruptions? Similarly, their historical claims are something of a leap.

\section{According to Beauregard and O'Leary (2008):}

Indeed, it is safe to say that (1) most people who have RSMEs, are not epileptics; and (2) very few epileptics report RSMEs during seizures. If epilepsy really produced RSMEs, all or most epileptics would have them. Clearly, epilepsy simply does not play the role that Saver and Rabin have suggested. (p. 71)

Beauregard and his colleagues have carried out their own studies of the brains of Carmelite nuns in prayer. They have concluded that the TLE hypothesis is groundless and have also gone on to distinguish RSMEs from merely emotional states by contrasting the mystical experiences from the brain profile of remembering autobiographical material (Beauregard \& O'Leary 2008: 274).

\section{The God helmet}

This brings us to what has come to be called 'the strange case of the God helmet'.

In a study published in Journal of Nervous and Mental Disorders (2002), Persinger and Faye Healey reported that under double-blind conditions, they had exposed 48 right-handed university students (24 men and 24 women) to weak (100 nT to $1 \mu \mathrm{T})$, complex, pulsed magnetic fields. The fields chosen were not much stronger than the ones a computer monitor or a cell phone would generate. Two-thirds of the subjects reported a sensed presence under the influence of the magnetic fields. But 33\% of the control (sham-field) group reported a sensed presence too. In other words, Persinger 
found that twice as many subjects reported a sensed presence under the magnetic field as those who reported one without a magnetic field (Beauregard \& O'Leary 2008: 83).

Persinger and his colleagues have gone on to test their device on over a 1000 people. While many of them have reported strange and sometimes terrifying experiences, many of them (including atheist writer Richard Dawkins) reported experiencing nothing at all. There is even reportedly a commercial version of the God helmet, marketed to assist people in their spiritual quest. Significantly, the electromagnetic pulses are applied to the same area that Ramachandran, Saver and Rabin hypothesise as the seat of the action, namely, the left temporal lobe. Some attempts to duplicate Persinger's results have failed but he has stood by his findings. Unfortunately, the media have tended to sensationalise the findings (Beauregard \& $\mathrm{O}^{\prime}$ Leary 2008:86-89).

Underlying Persinger's work is his conviction that anomalous electromagnetic fluctuations - produced by solar flares, seismic activity, radio and microwave transmissions, electrical devices and other external sources, or originating in the brain itself - can trigger disturbances resembling epileptic seizures. These 'micro seizures', he proposes, generate a wide range of altered states, including religious and mystical visions, out-of-body experiences and even alien-abduction episodes (Horgan 2003:91).

Once again, we can make the following distinction: a relationship between electromagnetic fields of whatever nature and spiritual experiences may well be a genuine correlation. However, what this means in terms of causal mechanisms and reductive explanations is another matter altogether. Religious practitioners of all faiths have used chanting, fasting, incense, sounds and the seasons, even the hours of the day, to regulate their state of mind for the best receptivity to the energies of the spirit. We should not be surprised if this turns out to have a neurological basis - that is exactly what we would expect.

After years of research ... our understanding of various key brain structures and the way information is channelled along neural pathways led us to hypothesise that the brain possesses a neurological mechanism for self-transcendence. The mind remembers mystical experience with the same degree of clarity and sense of reality that it bestows upon memories of 'real' past events. The same cannot be said of hallucinations, delusions, or dreams. We believe that this sense of realness strongly suggests that the accounts of the mystics are not indications of minds in disarray, but are the proper, predictable neurological result of a stable, coherent mind willing itself into a higher spiritual plane. (Newberg, D'Aquili \& Rause 2001:145-146)

\section{Why God won't go away?}

Researcher Andrew Newberg represents perhaps the most balanced treatment of the topic we will encounter. Without seeking to prove or 'explain away' the content of religious and spiritual experience, his work represents an attempt to describe what is going on in the brain when such experiences are taking place. Significantly, his conclusions are supported by other researchers such as Beauregard and O'Leary (2008) whom we have referenced a number of times so far:

The brain mediates but does not produce RSMEs. There is no scientific evidence showing that delusions or hallucinations produced by a dysfunctional brain can induce the kind of longterm positive changes and psycho-spiritual transformations that often follow RSMEs. In fact, delusions and hallucinations usually constitute negative experiences from a subjective perspective. (p. 292)

In addition, what all the research we have examined so far represents, despite all the ideological debates, can actually be brought together in an integrated way. Both Newberg and Beauregard have identified a number of areas of the brain that are involved in spiritual experience, including the temporal lobe and limbic system so exaggerated by Ramachandran, Saver and Rabin. We can agree with Boyer that our human evolution has predisposed us to a capacity for religion and with Alper that this has been passed down, albeit not exclusively, through genetically acquired traits.

Whether Hamer is correct about gene VMAT2 or not, some genetic mechanisms may well be involved to some extent as may Persinger's electromagnetic fluctuations in the temporal lobe.

\section{The spiritual brain}

According to Christian philosopher Alvin Plantinga (2000):

To show that there are natural processes that produce religious belief does nothing, so far, to discredit it; perhaps God designed us in such a way that it is by virtue of those processes that we come to have knowledge of him. Suppose it could be demonstrated that a certain kind of complex neural stimulation could produce theistic belief ... Clearly, it is possible both that there is an explanation in terms of natural processes of religious belief (perhaps a brain physiological account of what happens when someone holds religious beliefs), and that these beliefs have a perfectly respectable epistemic status. (p. 145)

So, to return to our original question: are we wired for God? The answer seems to be a most definite 'yes' if the claims of neurotheology are carefully considered. While there are many different approaches to the subject, what we have found is that on the whole most of them are fairly 'loaded' philosophically with an ideological agenda, mostly of the materialist variety as attempts not so much to explain spiritual experience but as to explain away the phenomenon. On the other extreme, it has been argued that Beauregard's attempt to provide a non-materialist argument ultimately also succumbs to a mixed agenda; while on the one hand the research and the analysis of the various other theories he provides is extremely useful, his vague defence of the soul is ultimately unsatisfactory. Newberg seems to come closest to a balanced perspective, albeit that his openness to spirituality 
seems to have earned him some criticism from some of his more tough-minded peers. In the final section below, we will examine some alternative approaches, for the sake of completeness, to the question we've been examining, from sources outside the field of neurotheology. For example, here is McIlhenny (2009) giving a biblical perspective:

\begin{abstract}
After reading The Spiritual Brain, along with a host of similar works, my immediate reaction as a Christian in the Reformed Calvinistic tradition has been, 'Well of course humans are hardwired for God; that's exactly what Romans 1 talks about'. Whether there is an actual sector of the brain that scientists can identify as the God module (and, frankly, I find Beauregard's refutation of this quite convincing), the apostle Paul presents the reality that all humans - all brains, let us say - know God, and not just any God. The brain is endowed with an intricate 'cognitive mechanism' (Plantinga's terminology) to produce a basic belief in the true and living God. (p. 1)
\end{abstract}

William James (1902), also, is consistently refreshing and eloquent, albeit that his insights come to us from 100 years ago: something pre-existing in us responds to the mystics because it resonates with what they have touched:

The study of the mystics, the keeping company, however humbly with their minds, brings with it as music or poetry does - but in far greater degree - a strange exhilaration, as if we were brought near to some mighty source of Being, were at last on the verge of the secret which we all seek. The symbols displayed, the actual words employed, when we analyse them, are not enough to account for such effect. It is rather that these messages from the waking transcendental self of another, stir our own deeper selves in their sleep. (p. 80)

\section{Spiritual evolution}

In a recent publication, psychiatrist and positive psychology pioneer George E. Vaillant, has argued that we are 'wired for faith, hope and love'. Basing his argument on both evolution and brain research, he suggests that there have been three great evolutionary transitions, namely the genetic, the cultural and the psychological. He connects the third evolution to human adult development and positive emotions. While in his view biology provides the underpinnings of positive emotions and spirituality, it is clear nonetheless that he is not attempting to reduce the one to the other (Vaillant 2008:64). His way of thinking provides a respectful non-reductionist approach to the findings we have explored above and a fitting place to draw our discussion to a conclusion.

Given the broadly reductionistic tendencies that have been a feature of the field of neurotheology almost from the beginning, it is not too surprising that the term has more or less been abandoned and the field replaced by Contemplative Neuroscience. This seems to be more in line with what Aldous Huxley, who coined the term 'neurotheology', probably had in mind in the first place (Huxley 1962:112). While we see the same neuro-scientific tools and techniques, there is more of a concern to appreciate the first person perspective and to avoid the trap of 'neuro-nonsense' warned about by Roger Scruton (2012:23), or the 'neuro-mania' warned about by Raymond Tallis (2014).

What is Contemplative Science? Also referred to as Contemplative Studies and Contemplative Neuroscience, depending on which aspect the writer wishes to emphasise, Contemplative Science is in many respects the heir to Neurotheology. Whereas Religious Studies approaches Religion from the perspectives of Psychology, Philosophy, Sociology and Anthropology, and somewhat later, has incorporated aspects of Phenomenology, the rise of the new inter-disciplinary field of Cognitive Science (more correctly The Cognitive Sciences [Sobel \& Li 2013] comprising cognitive psychology, neuroscience, artificial intelligence, linguistics, evolutionary psychology, and philosophy) and new measurement tools such as Biofeedback and fMRI have made it possible to examine the effects of contemplative practices on the brain more precisely.

The field of Contemplative Studies received an additional boost in 1990 when Tibetan spiritual leader His Holiness the Dalai Lama and biologist Francisco Varella co-founded the Mind and Life Institute and the scientific study of 'mindfulness' was born. In a very short period of time, the concept of mindfulness has gone mainstream. We now hear regularly about mindful parenting, mindful business, mindful golf, etc., prompting some reviewers to refer, somewhat cynically, to 'McMindfulness' (Purser 2013).

Spirituality as a discipline has much in common with Contemplative Studies, although the two fields have developed somewhat differently. Whereas Contemplative Studies primarily developed from out of Religious Studies, the discipline of Spirituality came mainly out of Theology (particularly Catholic) (Sheldrake 1998). The Cognitive Sciences have not had as much of an impact on the discipline of spirituality as yet, but that is simply a question of time. Already there have been a few studies on the effects of prayer on the brain and body. Moreover, Cognitive Studies has begun to make an impact on Theology (Peterson 2003).

There are significant methodological and philosophical issues in applying the primarily objective tools of Cognitive Science to the primarily subjective experiences of contemplation and prayer. The reductive tendencies of an over-zealous scientism are a particular danger to be aware of as has been pointed out above. Nevertheless, in our time we are uniquely placed to bring a new approach to the investigation of the truth claims of the spiritual traditions.

\section{Conclusion}

In conclusion, therefore we can draw a distinction between two central claims that constitute the approach of neurotheology. On the one hand, there are the various correlations made between spiritual experience of whatever nature and evolutionary development, genetic or neurological. 
On the other hand, there are the unwarranted generalisations concerning issues in philosophy and theology which various thinkers have made either in support of a materialist or non-materialist perspective. What most of the thinkers on the materialism versus non-materialism divide fail to realise is that there is a third way - a way which transcends the monism or dualism which, however much they try to deny it, they fall into. That third way has been called emergent, eco-systemic or holistic and, while it still does not assume the existence of God or spirit, provides a modern yet caring way to think about the mind and the soul. The 'Emergence of Spirit' however is beyond the scope of this article and I have addressed it in other work. As human beings, we have been blessed with a body as well as a mind and we would not honour faith by neglecting science. Rather, we understand that faith begins where science ends, at the limits of what we can know with our minds. Nothing we have examined in this article either disproves or proves the reality of the object of faith. It most certainly does, however, support the claim that one way or the other, we are truly wired for spirit.

\section{Acknowledgements}

The author thanks Prof. Rex van Vuuren for his encouragement throughout the writing of this article.

\section{Competing interests}

The author declares that he has no financial or personal relationships which may have inappropriately influenced him in writing this article.

\section{References}

Alper, M., 2001, The "God" part of the brain: A scientific interpretation of human spirituality, Rogue Press, New York.
Appleyard, B., 2007, 'Review of the spiritual brain: A neuroscientist's case for the existence of the soul', Philadelphia Inquirer Book Review, viewed 07 August 2009, from http://www.freerepublic.com/focus/f-news/1904947/posts

Beauregard, M. \& O'Leary, D., 2008, The spiritual brain, Harper Collins, New York.

Begley, S., 2001, 'Your brain on religion: Mystic visions or brain circuits at work?', Newsweek, 07 May 2001, viewed 07 August 2009, from http://www. cognitiveliberty.org/neuro/neuronewswk.htm

Biello, D., 2007, 'Searching for God in the brain', Scientific American, viewed 07 August 2009, from http://www.sciam.com/article.cfm?id=searching-for-god-in-the-brain

Boyer, P., 2002, Religion explained: The human instincts that fashion gods, spirits and ancestors, Vintage, London.

Dawkins, R., 1989, The selfish gene, Oxford University Press, New York

Feit, J.S., 2003, Probing neurotheology's brain, or critiquing an emerging quasi-science, viewed 07 August 2009, from www.templeton-cambridge.org/.../jonathon_scott feit_-_probing_neurotheologys_brain.pdf

Hamer, D., 2004, The God gene: How faith is hardwired into our genes, Anchor Books, New York.

Horgan J., 2003, Rational mysticism: Spirituality meets science in the age of enlightenment, Mariner Books, New York.

Huxley, A., 1962, Island, Harper \& Row, New York.

James, W., 1902, The varieties of religious experience, Random House, New York.

Johnson, G., 2007, God is in the dendrites: Can neurotheology bridge the gap between religion and science? viewed 07 August 2009, from http://www.slate.com/ id/2165026/

Mcllhenny, R., 2009, 'The spiritual brain without God: Possible? A review of the spiritual brain: A neuroscientist's case for the existence of the soul, by Mario Beauregard and Denyse O'Leary', viewed 07 August 2009, from http://www. metanexus.net/magazine/tabid/68/id/10873/Default.aspx

Newberg, A., D’Aquili, E. \& Rause, V., 2001, Why God won't go away: Brain science and the biology of belief, Ballantine Books, New York.

'Neurotheology', Wikipedia, The Free Encyclopaedia, 22 July 2004, 10:55 UTC Wikimedia Foundation, Inc., viewed 07 August 2009, from http://en.wikipedia. org/wiki/Neurotheology

Peterson, G.R., 2003, Minding God: Theology and the cognitive sciences, Fortress Press, Minneapolis, MN.

Plantinga, A., 2000, Warranted Christian belief, Oxford University Press, Oxford.

Purser, R. \& Loy, D., 2013, Beyond McMindfulness, viewed 09 January 2017, from http:// www.huffingtonpost.com/ron-purser/beyond-mcmindfulness_b_3519289.html

Scruton, R., 2012, The face of God: The Gifford lectures, Continuum International Publishing Group, London.

Sheldrake, P., 1998, Spirituality and theology (Trinity \& truth), DLT Publications, London.

Sobel, C.P. \& Li, P., 2013, The cognitive sciences: An interdisciplinary approach, Sage, London.

Tallis, R., 2011, Aping mankind: Neuromania, Darwinitis and the misrepresentation of humanity, Acumen, New York.

Vaillant, G.E., 2008, Spiritual evolution: How we are hard-wired for faith, hope and love, New Broadway Books, New York. 